\title{
CORRESPONDENCE
}

The Editor,

Journal of Glaciology

SIR,

\section{Snow chemistry from Xixabangma Peak, Tibet}

Despite their value in understanding the chemistry of the atmosphere, few snow-chemistry studies have been conducted in remote areas, particularly in Asia. Studies to date have been limited to Nepal and India (Ikegami and others, 1978; Mayewski and others, 1981, 1983, 1984; Lyons and Mayewski, 1983). To add to these studies, we present chemical analyses of samples collected at an elevation of $6300 \mathrm{~m}$ on Xixabangma glacier, a north-north-easterly flowing glacier that descends from Xixabangma Peak (8012 m a.s.l.; lat. $28^{\circ} 21^{\prime}$ N., long. $85^{\circ} 47^{\prime}$ E.) in the Mount Everest area. A total of three fresh snowfalls were analyzed for chloride, nitrate, sulfate, and sodium.

Samples were collected (J.L.C.) in adherence with clean-sampling techniques (i.e. non-particulating masks and garments, and polyethylene gloves). Wide-mouth LPE bottles with polyethylene tops were used both as sample scoops and sample containers. Anion analyses were performed using a Dionex 2010 ion chromatograph with an AS-4 column, a $0.5 \mathrm{ml}$ sample loop and a $0.0021 \mathrm{M} \quad \mathrm{NaHCO}_{3} / 0.0017 \mathrm{M}$ $\mathrm{Na}_{2} \mathrm{CO}_{3}$ eluent. Sodium was analyzed via flame atomic absorption spectrometry using a Perkin-Elmer 2280 system. The average precision for chloride, nitrate, sulfate, and sodium was $3 \%, 5 \%, 3 \%$, and $10 \%$, respectively. Extra sample bottles were filled with Milli-Q water taken into the field and analyzed to serve as container and methodology blanks. Blank values were $\approx 1 \mu \mathrm{g} \mathrm{kg}^{-1}$ for chloride and nitrate, $\approx 2 \mu \mathrm{g} \mathrm{kg}^{-1}$ for sulfate, and $\approx 3 \mu \mathrm{g} \mathrm{kg}^{-1}$ for sodium. Although relatively few samples were collected as part of this study and no air-mass back trajectories are available, a general discussion of the chemical species concentrations for these samples is presented because of the uniqueness of this data set and the potential implications for future work in the area.

Few Asian snow-chemistry data are available for comparison with the Xixabangma glacier data (Table I). Most of the chloride values measured in this study are close to the only other chloride values of $14-174 \mu \mathrm{g} \mathrm{kg}^{-1}$ for fresh snow from Nun Kun in Ladakh, India (Mayewski and others, 1983). However, even the range of values for nitrite plus nitrate of $0-81 \mu \mathrm{g} \mathrm{kg}^{-1}$ from Nun Kun snow (Mayewski and others, 1983) and the mean $\left(<100 \mu \mathrm{g} \mathrm{kg}^{-1}\right)$ of snow in remote areas in general (Lyons and others, 1985) is notably less than the range of nitrate in this study.

The range in chemical concentrations (Table I) for the three fresh snow events combined is relatively diverse with values differing by factors of $\approx 8, \approx 3, \approx 6$, and $\approx 5$ for chloride, nitrate, sulfate, and sodium, respectively, despite the fact that all of the events occurred within 8 days of each other. The samples all appear similar physically, exhibiting stellar crystal form and densities of approximately $0.2 \mathrm{Mg} \mathrm{m}^{-3}$, with the only difference being the slightly higher temperature (Table I) for the 8 May 1984 event. Ratios of chloride to sodium and nitrate to sulfate are similar for 1 May and 9 May compared to 8 May. While the range of chloride and sodium values for the 8 May storm event is high, this storm event, relative to the 1 May and 9 May events, is still characterized by higher chloride to sodium ratios which are, in general, close to the value in sea-water $(\cong 1.8)$. In addition, the 8 May event has lower nitrate and sulfate values than the 1 and 9 May events.

Although the cause of the differences in chemistry of the Xixabangma glacier fresh snow events cannot be adequately inferred from the limited number of samples available for this study, the existence of such different chemical signatures is encouraging for future studies in the region.

Glacier Research Group and

Department of Earth Sciences, University of New Hampshire,

Durham, New Hampshire 03824, U.S.A.

United States Geological Survey, Denver Federal Center,

Denver, Colorado 80225 ,

U.S.A.

29 May 1986

\section{REFERENCES}

Ikegami, K., and others. 1978. Atmospheric aerosol particles observed in high altitude Himalayas, by K. Ikegami, J. Inoue, K. Higuchi, and A. Ono. Seppyo, Vol. 40, Special Issue, p. 50-55.

Lyons, W.B., and Mayewski, P.A. 1983. Nitrate plus nitrite concentrations in a Himalayan ice core. Geophysical Research Letters, Vol. 10, No. 12, p. 1160-63.

\section{TABLE I. CHEMICAL SPECIES CONCENTRATIONS IN FRESH SNOW $\left(\mu \mathrm{g} \mathrm{kg}^{-1}\right)$}

\begin{tabular}{lcr}
\multicolumn{2}{c}{ Sample description } & \\
Temperature & Date & Chloride \\
${ }^{\circ} \mathrm{F}\left[{ }^{\circ} \mathrm{C}\right]$ & 1984 & \\
$20[-6.7]$ & 1 May & 66 \\
$20[-6.7]$ & & 126 \\
$20[-6.7]$ & & 78 \\
& & \\
$28[-2.2]$ & 8 May & 527 \\
$28[-2.2]$ & & 106 \\
$26[-3.3]$ & 9 May & 215 \\
& & \\
& &
\end{tabular}

$\begin{array}{rcrcc}\text { Sodium } & \begin{array}{c}\text { Chloridel } \\ \text { Sodium }\end{array} & \text { Nitrate } & \text { Sulfate } & \begin{array}{c}\text { Excess } \\ \text { sulfate* }\end{array} \\ 54 & 1.22 & 463 & 404 & 395 \\ 75 & 1.68 & 463 & 484 & 466 \\ 67 & 1.16 & 512 & 542 & 531 \\ 267 & 1.97 & 193 & 92 & 18 \\ 51 & 2.37 & 169 & 95 & 80 \\ 205 & 1.05 & 560 & 593 & 563\end{array}$


Lyons, W.B., and others. 1985. Nitrate concentrations in snow from remote areas, by W.B. Lyons, P.A. Mayewski, and M.J. Spencer. [Abstract.] EOS. Transactions, American Geophysical Union, Vol. 66, No. 46, p. 891-92.

Mayewski, P.A., and others. 1981. Reconnaissance glacio-chemical studies in the Indian Himalayas, by P.A. Mayewski, W.B. Lyons, and N. Ahmad. Proceedings of the Eastern Snow Conference, 38th annual meeting, p. 45-58.

Mayewski, P.A., and others. 1983. Chemical composition of a high altitude fresh snowfall in the Ladakh Himalayas, by P.A. Mayewski, W.B. Lyons, and N. Ahmad. Geophysical Research Letters, Vol. 10, No. 1, p. 105-08.

Mayewski, P.A., and others. 1984. Interpretation of the chemical and physical time-series retrieved from Sentik Glacier, Ladakh, Himalayas, India, by P.A. Mayewski, W.B. Lyons, N. Ahmad, G. Smith, and M. Pourchet. Journal of Glaciology, Vol. 30, No. 104, p. 66-76.

SIR,

Winter-talus ridges, nivation ridges, and pro-talus ramparts

A "pro-talus rampart" is a ridge or ramp of debris that forms where clasts fall from a cliff face, slide, or roll across the surface of a perennial snow bank of somewhat standard dimensions, and accumulate at its base (Richmond, 1962; Washburn, 1973; Ballantyne, 1986). Recent studies have focused attention on the use of "pro-talus ramparts" as palaeoenvironmental indicators of severe periglacial conditions during the late Pleistocene and Holocene (Ballantyne, 1984, 1986; Butler, 1984, 1986). Because of their significance in palaeoenvironmental research, I was interested in the background and origin of the term "protalus rampart". In the course of this historical research, I have been consistently amazed at the injustice done to the individual who first described and named these features.

In 1912, R.A. Daly provided the first written description of what were much later called "pro-talus ramparts" (Daly, 1912, p. 593). He provided both a schematic drawing and photograph (p. 592) of these land forms, and named them in the following way:

"Since these special accumulations of debris are dependent on the formation of heavy snow-banks and on specially rapid frost-action before the summer heat has melted the snow in large measure, the wall-like piles may be called 'winter-talus ridges'" (Daly, 1912, p. 593).

Both the accompanying drawing and photograph are clearly labelled, i.e. named, as winter-talus ridges.

How, then, did these features come instead to be known as "pro-talus ramparts" (a term arguably more confusing and less descriptive as to origin than winter-talus ridge)? In 1933, Behre published a more broadly available article, in which he described land forms which were clearly winter-talus ridges. He called these features "nivation ridges" (Behre, 1933, p. 630). Behre correctly recognized the written description of these land forms in another earlier publication, by Crawford (1913, p. 34, pl. VIIA). Crawford did not provide a name/term for these land forms, and Behre therefore created his term for them, apparently never having been aware of the work of Daly (1912).

The following year, Kirk Bryan (1934) reviewed Behre's (1933) paper, and criticized the term "nivation ridges" as misleading, because of the use of the term nivation for the process of excavation around snow banks (Bryan, 1934, p. 656). Bryan went on to provide the first usage of the term "pro-talus rampart":

"The use of the same word (nivation) for these ramparts of blocks is likely to be misleading, and the reviewer suggests that 'protalus rampart' would be appropriate for the features." (Bryan, 1934, p. 656).
The term was adopted and apparently never challenged. Some later works have belatedly credited Daly with the first description of the features in question, but without acknowledging that Daly actually also named them.

The numerous examples include the works by Blagbrough and Breed (1967, p. 762), Rapp and Fairbridge (1968, p. 1107), Flint (1971, p. 134), Washburn (1973, p. 199), Embleton and King (1975, p. 140), and Richmond (1962, p. 61).

It should be categorically stated that: (1) neither Crawford (1913) or Behre (1933) used the term "winter-talus ridge"; (2) the originator of the term "winter-talus ridge" was Daly (1912), who did more than merely describe the features; and (3) Bryan (1934) introduced a redundant term because of a lack of familiarity with Daly's (1912) work, based partially on Behre's (1933) similar lack of familiarity. The term "pro-talus rampart" is not necessary, nor has it been so since 1912 .

Department of Geography,

University of Georgia,

Athens,

Georgia 30602,

U.S.A.

\section{August 1986}

\section{REFERENCES}

Ballantyne, C.K. 1984. The Late Devensian periglaciation of upland Scotland. Quaternary Science Reviews, Vol. 3, No. 4, p. 311-43.

Ballantyne, C.K. 1986. Protalus rampart development and the limits of former glaciers in the vicinity of Baosbheinn, western Ross. Scottish Journal of Geology, Vol. 22, No. 1, p. 13-25.

Behre, C.H., jr. 1933. Talus behavior above timber in the Rocky Mountains. Journal of Geology, Vol. 41, No. 6, p. $622-35$.

Blagbrough, J.W., and Breed, W.J. 1967. Protalus ramparts on Navajo Mountains, southern Utah. American Journal of Science, Vol. 265, No. 9, p. 759-72.

Bryan, K. 1934. Geomorphic processes at high altitudes. Geographical Review, Vol. 24, No. 4, p. 655-56.

Butler, D.R. 1984. A late Quaternary chronology of mass wasting for a small valley in the Lemhi Mountains of Idaho. Northwest Science, Vol. 57, No. 1, p. 1-13.

Butler, D.R. 1986. Pinedale deglaciation and subsequent Holocene environmental changes and geomorphic responses in the central Lemhi Mountains, Idaho, U.S.A. Géographie Physique et Quaternaire, Vol. 40, No. 1, p. 39-46

Crawford, R.D. 1913. Geology and ore deposits of the Monarch and Tomichi districts, Colorado. Colorado Geological Survey Bulletin 4.

Daly, R.A. 1912. Geology of the North American Cordillera at the forty-ninth parallel. Geological Survey of Canada. Memoir, No. 38.

Embleton, C., and King, C.A.M. 1975. Periglacial geomorphology. New York, Halstead Press.

Flint, R.F. 1971. Glacial and Quaternary geology. New

York, etc., John Wiley and Sons, Inc.

Rapp, A., and Fairbridge, R.W. 1968. Talus fan or cone; scree and cliff debris. (In Fairbridge, R.W., ed. The encyclopedia of geomorphology. New York, Halstead Press, p. 1106-09.)

Richmond, G.M. 1962. Quaternary stratigraphy of the La Sal Mountains, Utah. U.S. Geological Survey. Professional Paper 324.

Washburn, A.L. 1973. Periglacial processes and environments. New York, St. Martin's Press. 